\title{
CONTACTING APSA BY E-MAIL
}

apsa@apsa.com

membership@apsa.com

meeting@apsa.com

PS@apsa.com

publications@apsa.com

minority_id@apsa.com

PSN@apsa.com

advertising@apsa.com

apsr@ssc.msu.edu

information@apsa.com

Use this address for general inquries about APSA services not mentioned below.

send mail to this address to receive information about membership rates and services to APSA and it's organized sections. Request an address change or renew your membership (if you wish to transmit your credit card number by e-mail). Find out about joint memberships with ASA, ASIL, and AHA.

Find out future annual meeting dates and information, including the 1996 Call for Papers.

Use this address to submit material for the People in Political Science Section and for the "News and Notes" sections; Questions about deadlines and manuscript submissions.

Receive a list of APSA publications, find the status of an order, and place orders (if you wish to transmit your credit card number by e-mail).

Use this address to submit names of students who are candidates for the minority identification project and to request additional information about the program.

Send employment listings to the Personnel Service Newsletter, a monthly publication listing employment opportunities for political scientists.

Obtain insertion rates for advertising in PS, APSR, and the Annual Meeting Final Program.

Use this address to contact the editorial office of the American Political Science Review. Please note that instruction for submission of articles to the review are printed in each issue. The editorial office does not handle business issues. For address changes, advertising, or other non-editorial issues, please contact APSA headquarters at the e-mail addresses listed above.

For general information about APSA services this automated server will return specific files you request. There are files on membership, publications, research grants, fellowships, and more. Type "send list" in the subject field of your message to receive a list of available files

The APSA Political

Scientists on E-mail:

rudder@apsa.com

rhauck@apsa.com smann@apsa.com woodard@apsa.com brintnall@apsa.com

\section{Catherine Rudder, Executive Director}

Robert J-P Hauck, Deputy Director, Director of International Programs Sheilah Mann, Director of Educational Affairs

Maurice Woodard, Director of Minority Affairs

Michael Brintnall, Director of Professional Affairs 


\section{APSA ON THE INTERNET}

The American Political Science Association (APSA) e-mail addresses and gopher server allow political scientists faster, more efficient ways to access information and services.

\section{APSA GOPHER}

Located at apsa.trenton.edu and coordinated by Bill Ball, assistant professor of political science, Trenton State College. The APSA gopher provides an effective means of retrieving political science resources from the Internet. The APSA gopher server is currently averaging 180 accesses a day. Use the address below:

\section{apsa.trenton.edu root menu}

About the APSA Gopher

American Government Gopher at

Northwestern University

Comparative Politics

International Relations

Political Theory

Public Policy and Public Administration

Computers, Software \& Data

APSA Information \& Services

Conference Information

Journal Information

Scholarships, Fellowships, \& Grants

The Political Science List of Lists

E-Mail Directory of Political Scientists

Related Gophers and Reference Information

Questions and suggestions on other gopher links should be sent to Bill Ball at ball@trenton.edu.

\section{PSRT-L, THE POLITICAL SCIENCE} RESEARCH AND TEACHING LIST The APSA gopher server is designed to work in conjunction with the Political Science Research and Teaching List (psrt-1) which itself has 1,420 subscribers in 44 countries. PSRT-L is a Listserv discussion group (send the command "subscribe psrt-l your name" to listserv@mizzou1.missouri.edu). To send messages to current subscribers of the list, send mail to psrt-1@mizzoul.missouri.edu.

\section{WORLD WIDE WEB SITES FOR POLITICAL SCIENTISTS}

The World Wide Web (WWW) allows users to view text as well as graphics, video, and sound. Like the gopher, special software is needed to access web pages. The following sites contain information relevant to political science:

http://www.un.org

United Nations news and documents http://osiris.colorado.edu/ prq/prq.html Political Research Quarterly, the official journal of the Western Political Science Association

http://www.loc.gov

Documents from the Library of Congress

Information on other political science web sites should be sent to psrt-l@mizzou1.missouri.edu

\section{American Political Science Association}

1527 New Hampshire Avenue, NW

Washington, DC 20036

Phone: (202) 483-2512 e-mail: apsa@apsa.com Fax: (202) 483-2657 